\title{
Needs Analysis of Chinese English Majors in EGP Courses
}

\author{
Kexin Xu \\ School of English, Tianjin Foreign Studies University, Tianjin, China
}

\begin{abstract}
Based on the needs analysis model outlined by $\mathrm{Li}$ (2007), this study investigates the needs of Chinese English majors enrolled in EGP courses and identifies the gender differences in their needs from linguistic, cognitive, and affective perspectives. SPSS 23.0 was used in this study to analyze data obtained from 221 Chinese English majors through a revised version of Li's (2007) questionnaire. The results showed that: 1) from the linguistic perspective, students revealed the strongest desire to practice pronunciation and speaking in class, attached the greatest importance to vocabulary and speaking, and had a conflict opinion of vocabulary. 2) from the cognitive perspective, students manifested aspirations for the teacher's positive feedback, a harmonious English learning environment, communicative learning activities, and the opportunity to practice in class. 3) from the affective perspective, students recorded the usefulness of English as their primary learning motivation, showing a broadly positive attitude and adequate confidence when learning English. 4) males preferred using the grammar-translation method to learn English and were more likely to be motivated by their desires to understand the information in English; females favored adopting the communicative method to learn English and were more likely to be stimulated by school's requirement and their cravings for good grades. This research endeavor is considered significant because its finding can be used to assist Chinese teachers and course designers to develop the rarely-examined EGP courses provided for Chinese English majors based on the often-overlooked students' needs.
\end{abstract}

Index Terms—needs analysis, learners' needs, Chinese English majors, English for General Purposes

\section{INTRODUCTION}

English courses at the tertiary level in China are often divided into two categories: English for General Purposes (EGP) courses and English for Specific Purposes (ESP) courses (Liu, Chang, Yang \& Sun, 2011). ESP courses primarily teach students fluent English concerning specific disciplines or for communicative purposes in specific situations (Hutchinson \& Waters, 1987). In comparison, EGP courses focus on cultivating wider knowledge of the English language and improving the overall linguistic ability of students regarding their accurate and proficient uses of English in general situations (Munby, 1978).

To meet the demand for international talents following China's entry into the World Trade Organization, in 2000 China proposed the National English-teaching Curriculum for English Majors in Universities (hereafter referred to as the Curriculum). The Curriculum determines the key teaching objective for English majors as the cultivation of interdisciplinary English talents who can use English proficiently in specific subjects (Cai, 2019). Due to this proposed teaching objective, courses for English majors in Chinese universities are predominantly ESP-based (Hu, 2014). Nevertheless, problems of this interdisciplinary cultivation mode have been gradually revealed with the continuous expansion of enrollment of English majors in Chinese universities: 1) excessive emphasis is paid to the instrumental nature of English, with Cha (2017) stating that "this pragmatic and utilitarian approach towards English education differentiated this discipline from other humanities" (p. 18). 2) time allocated for students' learning English is reduced since more time must be spent on learning other professional knowledge, with a subsequent decline in the students' mastery of basic English ability and knowledge (Wen \& Wei, 2018). Hence, numerous scholars begin to reexamine the rationality of this cultivation mode (Cha, 2017; Hu, \& Sun, 2006; Lan, 2009; Wen \& Wei, 2018).

As a result, "the cultivation of interdisciplinary talents has been finally excluded" from the newly released The National Quality Standards for Foreign Language Majors (hereafter referred to as the National Standards) in 2018 (Cai, p. 6, 2019). Instead, the National Standards resets the teaching objective, with focus placed on cultivating English majors who have both solid basic English language skills and interdisciplinary English skills. The importance of building a diversified English courses system is highlighted to achieve the all-round cultivation of English majors. This suggests the necessity of developing both ESP and EGP courses, thereby enabling students to use English proficiently in both specific and general situations. However, influenced by the previous interdisciplinary cultivation mode, most domestic studies concerning English major courses are conducted in ESP courses while scarce are the studies carried out in EGP courses. As such, it is essential to focus on the development of EGP courses for English majors.

The initial and crucial step in developing language courses is needs analysis (Hutchinson \& Waters, 1987). Needs analysis, according to Brown (1995), is "the systematic collection and analysis of all subjective and objective information necessary to define and validate defensible curriculum purposes that satisfy the language learning requirements of students within the context of particular institutions that influence the learning and teaching situation" 
(p. 36). The vital role played by needs analysis in designing, evaluating, and optimizing nearly all aspects of English courses demonstrates the necessity for course designers and teachers to develop English courses through needs analysis (Munby, 1978). Therefore, this study will conduct needs analysis in EGP courses provided for Chinese English majors to collect key data that course designers can reference.

\section{LITERATURE REVIEW}

\section{A. Learners' Needs as Data Sources for Needs Analysis}

Society, teachers, and students are the primary data sources for needs analysis (West, 1994; Shu, 2004). Social needs refer to the normative requirements of social company concerning the linguistic ability expected of students by the time their courses culminate; teachers' needs concern the expectations of educators regarding the linguistic knowledge that students should learn; learner needs are the personal desires of students regarding what they need and want to learn on their courses (Long, 2005). Numerous scholars have emphasized that the needs of learners - the subjects undertaking the courses - should arguably be the focus of needs analysis (Shu, 2004; Dudley-Evans \& John, 1998; Hutchinson \& Waters, 1987; Nunan, 1988). Addressing the needs of learners is a prerequisite of developing student-centered English courses (Liu, et al., 2011; Nunan, 1988). However, many Chinese scholars have highlighted in their researches that the needs of students are frequently ignored by Chinese universities (Li, 2007; Zhao, Lei \& Zhang, 2009; Zhu, 2015). Because English teaching departments in these institutions tend to design courses from a top-down perspective, with ideas from teaching staff and employers adopted and prioritized while the opinions of students regarding their courses are neglected (Zhao, Lei \& Zhang, 2009).

Nevertheless, basing needs analysis on the objective observations and expectations of teachers and employers may cause the fact that the aspirations of learners cannot be fully comprehended (Hutchinson \& Waters, 1987; Nunan, 1988; Liu, et al., 2011). By neglecting the needs of learners, the language courses that students need and the actual courses may be mismatched (Li, 2007). For example, a study conducted by Oanh (2007) identified significant gaps between the materials used in English courses and the needs reported by students. The material was deemed by the students as outdated, too theoretical, and ultimately conflicted with their overall linguistic proficiency. Similarly, a study conducted by Nouri and Mazdayasna (2014) revealed the frustration felt by students regarding their English courses and their corresponding desires for a systematic, contemporary and student-centered pedagogical framework. The dissatisfaction of English majors regarding the translation course was highlighted in the study of Wang (2014), in which students stipulated that more authentic materials and more learning activities which could increase interactions between teachers and students were required on their courses. Zhang (2018) found that redundant content was excessive in college English courses with the same knowledge repeated, resulting in a misalignment with the desires of students for new content and course innovation.

As highlighted by these studies, the conflict between the actual English syllabus and what Li (2007) terms the "learners' syllabus" (p. 17) may result in the decreased learning motivation and interest of students, subsequently leading to the declining efficiency of foreign language courses, undesirable teaching results, and wasted teaching resources (Long, 2005). Therefore, to help instructors and course designers understand students' desires, thereby making English courses more student-centered, it is essential to conduct needs analysis in which the data sources are the needs of learners (Liu, et al., 2011).

\section{B. Needs Analysis in ESP and EGP Courses}

As ESP courses have specific purposes in language teaching, learners tend to understand their needs more accurately and ESP specialists "are often needs assessors first and foremost, then designers and implementers of specialized curricula in response to identified needs" (Belcher, p.135, 2006). Hence, needs analysis is often conducted in ESP courses to investigate learners' needs (Liu, et al., 2011; Hutchinson \& Waters, 1987). In contrast, EGP courses are "more usefully considered as providing a broad foundation rather than a detailed and selective specification of goal like ESP" (Far, p. 3, 2008). Thus, EGP courses seem to lack the same concerns of learners' needs because of "an erroneous belief that it is not possible to specify the needs of general English learners" (Seedhouse, p. 59, 1995).

However, numerous studies have proved that learners' needs in EGP courses can be specified. Seedhouse (1995) conducted a study investigating the needs of Spanish teenagers enrolled in EGP courses. He discovered that the students were driven to learn English by specific psychological and social needs, such as for travel purposes or by their desires to obtain a better job. Liu, et al. (2011) and Ahour and Mohseni (2015) used the same questionnaire to examine the needs of EGP students in Taiwan and Iran respectively. These two studies both determined that students regarded speaking and writing as the most necessary skills taught in EGP courses, with the latter being the skill the students desired most to learn but the one at which they felt most insufficient. Students also possessed clear short-term and long-term academic goals, which significantly influenced their perceived needs. Behzadi and Lashkarian (2015) and Mehrdad (2012) revealed the desire of the Iranian students enrolled in an EGP course to extend their vocabulary and strengthen grammar. Similarly, students from Moiinvaziri's (2014) study considered vocabulary, grammar, and reading to be the most essential English components to learn, on which they felt they should have the most practice. The students further identified the completion of their studies to be the top reason for learning English, while reporting the communicative learning as their preferred learning style. 
These studies suggest the feasibility of applying needs analysis to investigate students' needs which are generally believed as less discernable in EGP courses (Nunan, 1988; Liu, et al., 2011).

\section{Related Needs Analysis Studies on Courses for Chinese English Majors}

Needs analysis studies concerning Chinese English majors mainly focus on their ESP courses.

Many scholars conducted needs analysis to optimize the content of ESP courses. Su's (2011) study found that consecutive interpretation courses in mainland China failed to focus on the cultivation of students' Chinese proficiency which was needed by students. He proposed that the courses should add content like Chinese culture and applied Chinese to improve students' ability to apply Chinese when doing the interpretation. Li (2014) and Xie (2016) both emphasized in their studies the importance of combining business knowledge, English language ability, and comprehensive quality in business-focused English language courses which could better cultivate business English talents that meet the society's needs. Ye and Wang (2019) proposed that the interdisciplinary legal English courses should scientifically integrate legal professional knowledge and English language skills to meet the learning needs of students.

Various researchers used needs analysis to improve the teaching materials and teaching methods in ESP courses. A study conducted by Guiyu and Yang (2016) highlighted the frustration of business English majors in Guangdong University of Foreign Studies regarding the simplicity of the teaching materials which were unable to meet their expectations. The study determined the desire of students for updated textbooks with practical, targeted, interesting, and communicated-focused material. The necessity of combining online and offline teaching was mentioned in a study conducted by Lü, Fu, and Ruan (2014), which established an innovative method for teaching English film courses to undergraduates in the Communication University of China. Xie (2019) proposed that teachers must realize the importance of electronic media in addition to print media in English teaching, thereby satisfying students' needs for diversified ways of learning. Based on the needs of English undergraduates enrolled in Electric English courses at Shanghai Electric Power University, Yu (2011) proposed a flexible teaching method that combined methods of grammar-translation, register analysis, and computer-assisted teaching.

With needs analysis studies mainly conducted in ESP courses, few of them have focused on EGP courses provided for English majors in China. Nevertheless, ESP and EGP courses are designed to meet students' different needs for learning English and develop their different English abilities (Liu, et al., 2011). Both ESP and EGP courses are deserving of research attention to achieve the all-round cultivation of English majors outlined by the National Standards.

\section{Theoretical Background: Li's (2007) Needs Analysis Model}

The needs analysis model of Li (2007) which is initially applied in the Chinese EFL (English as a Foreign Language) context, further employed by Moiinvaziri (2014) when examining the needs of Iranian students in EGP courses, will be used in this study. Li (2007) proposes that the needs of students can be analyzed from linguistic, cognitive, and affective perspectives.

1) The linguistic perspective addresses the viewpoints of students regarding what they need to learn in their English courses. For subjects of this study — English majors at Tianjin Foreign Studies University, the content of their EGP courses is mainly the teaching of three English components (grammar, vocabulary, and pronunciation) and four English skills (listening, speaking, writing, and reading), all of which will be considered in this study.

2) The cognitive perspective investigates the cognitive variables of learners during the English learning process. Language learning is an internally-generated process in which the cognitive processing mechanism may play a vital role, thus highlighting the necessity of including cognitive variables in the needs analysis model (Li, 2007). Cognitive variables examined in Li's (2007) study, such as students' preferred learning styles, students' preferred learning activities, and students' expectations on the role of teachers will be explored in this study.

3) The affective perspective examines the affective variables of learners during the English learning process. As Li (2007) suggests, "Learning a language is an emotional experience, and the feeling that the learning process evokes will have a crucial bearing on the success or failure of the learning" (p. 21). As such, Li (2007) investigated the motivation, attitude, and confidence of learners when learning English, and these three variables will also be included in this study.

\section{RESEARCH PURPOSE AND RESEARCH QUESTIONS}

In response to the aforementioned research gaps, this study aims to investigate the needs of Chinese English majors engaged in EGP courses from linguistic, cognitive, and affective perspectives based on Li's (2007) needs analysis model. Considering that many studies have proven gender's influence on the needs of students (Moiinvaziri, 2014; Pourshahian, Gholami, Vaseghi \& Kalajahi, 2012; Zhu \& Ma, 2014), this study will further examine how gender affects the reported needs of students.

This study will attempt to answer the following research questions:

1) What are Chinese English majors' views of English components (grammar, vocabulary, and pronunciation) and English skills (listening, speaking, writing, and reading) that they need to learn in EGP courses? (linguistic perspective)

2) What are Chinese English majors' preferred learning styles, favored learning activities, and expectations on the 
role of teachers in EGP courses? (cognitive perspective)

3) What are Chinese English majors' learning motivation, attitude, and confidence in EGP courses? (affective perspective)

4) Is there any difference in these three perspectives between male and female students?

\section{METHODOLOGY}

\section{A. Participants}

Participants of this study were comprised of 221 first-year and second-year Chinese English majors (73 males and 148 females) from Tianjin Foreign Studies University (TFSU). Their demographic information is documented in Table 1. According to the educational policy of TFSU, EGP courses are compulsory for freshman and sophomore English majors, making them suitable subjects for this study.

TABLE I

DEMOGRAPHIC INFORMATION OF PARTICIPANTS

\begin{tabular}{lllc}
\hline Demographic & Subcategories & N & Percentage \\
\hline \multirow{2}{*}{ Gender } & Male & 73 & $33.0 \%$ \\
& Female & 148 & $67.0 \%$ \\
\multirow{2}{*}{ Grade } & Freshmen & 110 & $49.8 \%$ \\
& Sophomores & 111 & $50.2 \%$ \\
\hline
\end{tabular}

\section{B. Instrumentation}

This study adopted $\mathrm{Li}$ (2007) questionnaire which was made based on his needs analysis model and consisted of four parts: Part A was used to obtain the background information of students; Part B was designed from the linguistic perspective, aiming to investigate students' opinion of what they need to learn in their language courses; Part C and Part D were devised from the cognitive and affective perspective, hence the former concerned students' cognitive variables while the latter explored students' affective variables.

Several adjustments to the questionnaire were made: Questions 8-10 in part B were deleted because linguistics courses were not provided for first-year and second-year English majors, hence they failed to know technical terms like stress, intonation, and usage. Besides, the low-grade students were not proficient enough to have an in-depth knowledge of grammatical rules. Questions 11 and 12 in part B, as well as question 4-8 in part C - which respectively concerned problems that students encountered when learning English, the opinions of students regarding the benefits of learning English, students' reactions to mistakes, students' views regarding the necessity of planning study, and students' responses to class test and feedback — were omitted due to these questions' irrelevances to the research questions of this study. The revised questionnaire (Appendix A) was examined by two experts for comprehensibility and then piloted among 30 students. This questionnaire enjoyed high reliability with the Cronbach-alpha of 0.875 .

\section{Data Collection and Analysis}

The researcher gave paper questionnaires to students in their classrooms and, with the teacher's assistance, collected the questionnaires following their completion. Students were assured that all answers would be kept confidential and no personal information would be divulged. 221 questionnaires were collected with a return rate of $100 \%$. The process of collecting and administering the questionnaires took roughly two weeks.

Data from the collected questionnaires were typed into SPSS 23.0. Descriptive analysis methods were employed to compare means for all questions. Independent samples $t$-test (questions 1-7, question 9, and question 12-13) and chisquare test (question 8 and questions 10) were then adopted, at a significant level of .05, to determine the impact of gender on the needs of students.

\section{RESULtS}

\section{A. Linguistic Perspective}

Question 1 to question 3 asks, respectively, the views of students on the importance, expected practice, and difficulty of English components (grammar, vocabulary, and pronunciation). The results in Table 2 reveal that students regard vocabulary as the most important component of English $(M=4.35, S D=0.88)$ and view grammar as the most difficult component to learn $(M=3.67, S D=1.07)$. The results further show that students want to practice pronunciation most in class $(M=4.14, S D=0.96)$. Significant gender differences have been found: females $(M=4.49, S D=0.80)$ demonstrate higher recognition than males $(M=4.05, S D=0.96)$ regarding the importance of vocabulary, $t(219)=-$ $3.58, p<.05$; females $(M=4.34, S D=0.92)$ also attach more importance than males $(M=4.07, S D=0.89)$ to pronunciation, $t(219)=-2.11, p=.035$. 
TABLE II.

THE VIEWS OF STUDENTS REGARDING ENGLISH COMPONENTS

\begin{tabular}{|c|c|c|c|c|c|c|}
\hline Q1 (Importance) & Gender & Mean & SD & df & $\mathrm{t}$ & Sig. (2-tailed) \\
\hline & Male & 3.81 & 0.95 & & & \\
\hline \multirow[t]{3}{*}{ Grammar } & Female & 3.81 & 1.07 & 219 & -.02 & .986 \\
\hline & Total & 3.81 & 1.03 & & & \\
\hline & Male & 4.05 & 0.96 & & & \\
\hline \multirow[t]{3}{*}{ Vocabulary } & Female & 4.49 & 0.80 & 219 & -3.58 & .000 \\
\hline & Total & 4.35 & 0.88 & & & \\
\hline & Male & 4.07 & 0.89 & & & \\
\hline \multirow[t]{2}{*}{ Pronunciation } & Female & 4.34 & 0.92 & 219 & -2.11 & .035 \\
\hline & Total & 4.25 & 0.92 & & & \\
\hline \multirow[t]{2}{*}{ Q2 (Practice) } & Gender & Mean & SD & df & $\mathrm{t}$ & Sig. (2-tailed) \\
\hline & Male & 3.90 & 0.96 & & & \\
\hline \multirow[t]{3}{*}{ Grammar } & Female & 3.89 & 0.95 & 219 & .09 & .929 \\
\hline & Total & 3.90 & 0.95 & & & \\
\hline & Male & 3.79 & 1.09 & & & \\
\hline \multirow[t]{3}{*}{ Vocabulary } & Female & 3.87 & 0.94 & 219 & -.54 & .588 \\
\hline & Total & 3.85 & 0.99 & & & \\
\hline & Male & 4.00 & 0.97 & & & \\
\hline \multirow[t]{2}{*}{ Pronunciation } & Female & 4.20 & 0.95 & 219 & -1.48 & .141 \\
\hline & Total & 4.14 & 0.96 & & & \\
\hline \multirow[t]{2}{*}{ Q3 (Difficulty) } & Gender & Mean & SD & $\mathrm{df}$ & $\mathrm{t}$ & Sig. (2-tailed) \\
\hline & Male & 3.63 & 1.14 & & & \\
\hline \multirow[t]{3}{*}{ Grammar } & Female & 3.68 & 1.04 & 219 & -.34 & .734 \\
\hline & Total & 3.67 & 1.07 & & & \\
\hline & Male & 3.53 & 1.14 & & & \\
\hline \multirow[t]{3}{*}{ Vocabulary } & Female & 3.40 & 0.97 & 219 & .92 & .358 \\
\hline & Total & 3.44 & 1.03 & & & \\
\hline & Male & 3.49 & 1.16 & & & \\
\hline \multirow[t]{2}{*}{ Pronunciation } & Female & 3.26 & 1.08 & 219 & 1.50 & .135 \\
\hline & Total & 3.33 & 1.11 & & & \\
\hline
\end{tabular}

Question 4 to question 7 asks, respectively, the importance that students place on four skills of English (listening, speaking, reading, and writing), the frequency of their engagements with these skills, and their proficiency and expected practice of each skill. Table 3 shows that speaking is regarded as the most crucial skill $(M=4.10, S D=1.08)$. Students also show that they engage most frequently with the listening $(M=3.44, S D=1.15)$, choose speaking as what they want to practice most in class $(M=3.86, S D=1.07)$, and record listening as their most highly proficient skill $(M=3.19, S D=$ 1.02). One particularly significant difference between males and females is that males record higher proficiency in their uses of all four English skills.

Normally, in the process of learning English, what students consider most indispensable should align with what they are most eager to practice. As the results in Table 3 show that students choose speaking as the most crucial English skills and they also want to spend most of their time practicing it. However, the results in Table 2 establish the conflict in students' views of English vocabulary: students regard vocabulary as the most important component while they report the fewest desire to practice vocabulary in class. This similar conflict is also found in the studies of Moiinvaziri (2014) and $\mathrm{Li}$ (2007). This suggests that it may be a common phenomenon that students are unable to "make valuable decisions for their language development and progress to some extent” (Moiinvaziri, p 63, 2014). 
TABLE III.

THE VIEWS OF STUDENTS TOWARDS ENGLISH LANGUAGE SKILLS

\begin{tabular}{|c|c|c|c|c|c|c|}
\hline Q4 (Importance) & Gender & Mean & SD & $\mathrm{df}$ & $\mathrm{t}$ & Sig. (2-tailed) \\
\hline & Male & 4.04 & 0.95 & & & \\
\hline \multirow[t]{3}{*}{ Listening } & Female & 3.79 & 1.28 & 186.33 & 1.64 & .104 \\
\hline & Total & 3.87 & 1.19 & & & \\
\hline & Male & 4.25 & 0.83 & & & \\
\hline \multirow[t]{3}{*}{ Speaking } & Female & 4.03 & 1.18 & 192.91 & 1.60 & .111 \\
\hline & Total & 4.10 & 1.08 & & & \\
\hline & Male & 4.08 & 0.88 & & & \\
\hline \multirow[t]{3}{*}{ Reading } & Female & 3.79 & 1.07 & 171.23 & 2.16 & .033 \\
\hline & Total & 3.89 & 1.02 & & & \\
\hline & Male & 4.19 & 0.91 & & & \\
\hline \multirow[t]{2}{*}{ Writing } & Female & 3.67 & 1.13 & 173.92 & 3.71 & .000 \\
\hline & Total & 3.84 & 1.09 & & & \\
\hline \multirow[t]{2}{*}{ Q5 (Frequency) } & Gender & Mean & SD & $\mathrm{df}$ & $\mathrm{t}$ & Sig. (2-tailed) \\
\hline & Male & 3.56 & 1.31 & & & \\
\hline \multirow[t]{3}{*}{ Listening } & Female & 3.39 & 1.05 & 119.13 & 1.00 & .319 \\
\hline & Total & 3.44 & 1.15 & & & \\
\hline & Male & 3.59 & 1.05 & & & \\
\hline \multirow[t]{3}{*}{ Speaking } & Female & 3.05 & 1.07 & 219 & 3.52 & .001 \\
\hline & Total & 3.23 & 1.09 & & & \\
\hline & Male & 3.73 & 0.89 & & & \\
\hline \multirow[t]{3}{*}{ Reading } & Female & 3.28 & 1.03 & 219 & 3.14 & .002 \\
\hline & Total & 3.43 & 1.00 & & & \\
\hline & Male & 3.45 & 1.17 & & & \\
\hline \multirow[t]{2}{*}{ Writing } & Female & 2.84 & 1.02 & 128 & 3.83 & 0.00 \\
\hline & Total & 3.04 & 1.11 & & & \\
\hline \multirow[t]{2}{*}{ Q6 (Proficiency) } & Gender & Mean & SD & $\mathrm{df}$ & $\mathrm{t}$ & Sig. (2-tailed) \\
\hline & Male & 3.60 & 1.01 & & & \\
\hline \multirow[t]{3}{*}{ Listening } & Female & 2.98 & 0.97 & 219 & 4.44 & .000 \\
\hline & Total & 3.19 & 1.02 & & & \\
\hline & Male & 3.52 & 1.06 & & & \\
\hline \multirow[t]{3}{*}{ Speaking } & Female & 2.91 & 1.00 & 219 & 4.17 & .000 \\
\hline & Total & 3.11 & 1.06 & & & \\
\hline & Male & 3.52 & 0.91 & & & \\
\hline \multirow[t]{3}{*}{ Reading } & Female & 2.76 & 0.94 & 219 & 5.74 & .000 \\
\hline & Total & 3.01 & 1.00 & & & \\
\hline & Male & 3.66 & 0.92 & & & \\
\hline \multirow[t]{2}{*}{ Writing } & Female & 3.19 & 0.92 & 219 & 3.56 & .000 \\
\hline & Total & 3.01 & 1.00 & & & \\
\hline \multirow[t]{2}{*}{ Q7 (Practice) } & Gender & Mean & SD & $\mathrm{df}$ & $\mathrm{t}$ & Sig. (2-tailed) \\
\hline & Male & 3.58 & 1.20 & & & \\
\hline \multirow[t]{3}{*}{ Listening } & Female & 3.46 & 1.08 & 219 & .72 & .470 \\
\hline & Total & 3.50 & 1.12 & & & \\
\hline & Male & 4.12 & 0.88 & & & \\
\hline \multirow[t]{3}{*}{ Speaking } & Female & 3.72 & 1.14 & 179.38 & 2.88 & .004 \\
\hline & Total & 3.86 & 1.07 & & & \\
\hline & Male & 3.73 & 1.08 & & & \\
\hline \multirow[t]{3}{*}{ Reading } & Female & 3.29 & 0.99 & 219 & 2.98 & .003 \\
\hline & Total & 3.43 & 1.04 & & & \\
\hline & Male & 3.82 & 0.96 & & & \\
\hline \multirow[t]{2}{*}{ Writing } & Female & 3.37 & 1.03 & 219 & 3.13 & .002 \\
\hline & Total & 3.52 & 1.03 & & & \\
\hline
\end{tabular}

\section{B. Cognitive Perspective}

Question 8 examines the expectations of students regarding different teachers' roles (Appendix B). Students rank "The teacher responds to students positively" $(71.5 \%)$ as the primary role of teachers. This suggests that students regard encouragement and positive comment to be the more effective way of teaching than giving negative responses, such as reprimand and disappointment. Besides, the aspiration of students to learn in a stress-free environment in which they are offered a more active role and more freedom, rather than being governed by authoritative teachers, is shown in the statement ranked second-highest, "The teacher should create a harmonious and pleasant learning environment" (67.9\%), and the option ranked lowest, "The teacher is the 'authority' in the classroom" (10.4\%). Question 8 reveals significant gender differences regarding teachers' roles: more males $(20.5 \%)$ report being accustomed to authoritative teachers in the classroom than females $(5.4 \%), \chi^{2}=12.02, d f=1, p=.001$; more females $(77.7 \%)$ report a strong desire than males (58.9\%) for teachers' providing positive responses, $\chi^{2}=8.48, d f=1, p=.004$; more females $(74.3 \%)$ also want teachers to create a pleasant learning environment than males $(54.8 \%), \chi^{2}=8.55, d f=1, p=.003$.

Question 9 asks students to choose the most helpful learning activities out of 17 items provided, thereby investigating their preferred learning activities (Appendix C). They report "Reciting dialogues from a textbook" $(M=2.04, S D=0.69)$ 
to be the least helpful learning activities and they also score relatively low in 'Memorizing bilingual words list' $(M=$ 2.30, $S D=0.63$ ). This shows students' disfavor of learning English by rote memorization. On the contrary, students report "Talking to English speakers whenever I have the opportunity" $(M=2.52, S D=0.61)$ as the most beneficial learning activity. Apart from conversing with English speakers, students also give a high score to other activities that involved English communication, such as 'Chatting through the Internet in English' $(M=2.33, S D=0.67)$ and 'Talking to friends in English' $(M=2.40, S D=0.71)$. This reveals the strong desire of students to be involved in communicative learning activities, which correlates with the results of Moiinvaziri's (2014) study. In terms of significant gender differences, males $(M=2.42, S D=0.60)$ have higher recognition than females $(M=2.20, S D=0.61)$ of "Practicing drills on grammar patterns", $t(219)=2.57, p=.011$; males $(M=2.38, S D=0.70)$ also prefer "Doing English-Chinese exercises" than females $(M=2.19, S D=0.54), t(115.45)=2.09, p=.039$. This indicates that males are more in favor of studying English by using the traditional grammar-translation method.

TABLE IV.

THE PREFERRED LEARNING STYLES OF STUDENTS

\begin{tabular}{|c|c|c|c|c|c|}
\hline Q10 & Gender & Agree & $\mathrm{df}$ & $\chi^{2}$ & $\begin{array}{l}\text { Asymp.Sig. } \\
\text { (2-sided) }\end{array}$ \\
\hline \multirow{3}{*}{$\begin{array}{l}\text { The teacher gives lectures to } \\
\text { which I listen. }\end{array}$} & Male & $35.6 \%$ & \multirow{3}{*}{1} & \multirow{3}{*}{2.70} & \multirow{3}{*}{.100} \\
\hline & Female & $25.0 \%$ & & & \\
\hline & Total & $28.5 \%$ & & & \\
\hline \multirow{4}{*}{$\begin{array}{l}\text { The teacher gives lectures and } \\
\text { also provides me with } \\
\text { opportunities to practice. }\end{array}$} & Male & $60.3 \%$ & \multirow{3}{*}{1} & \multirow{3}{*}{10.24} & \multirow{3}{*}{.001} \\
\hline & Female & $80.4 \%$ & & & \\
\hline & Total & $73.8 \%$ & & & \\
\hline & Male & $31.5 \%$ & \multirow{3}{*}{1} & \multirow{3}{*}{.34} & \multirow{3}{*}{.558} \\
\hline \multirow[t]{2}{*}{ I study individually. } & Female & $27.7 \%$ & & & \\
\hline & Total & $29.0 \%$ & & & \\
\hline \multirow{3}{*}{$\begin{array}{l}\text { I discuss with my desk- } \\
\text { mates. }\end{array}$} & Male & $34.2 \%$ & \multirow{3}{*}{1} & \multirow{3}{*}{.11} & \multirow{3}{*}{.744} \\
\hline & Female & $36.5 \%$ & & & \\
\hline & Total & $35.7 \%$ & & & \\
\hline \multirow{3}{*}{$\begin{array}{l}\text { I discuss with my group } \\
\text { members }\end{array}$} & Male & $52.1 \%$ & \multirow{3}{*}{1} & \multirow{3}{*}{.44} & \multirow{3}{*}{.509} \\
\hline & Female & $56.8 \%$ & & & \\
\hline & Total & $55.2 \%$ & & & \\
\hline
\end{tabular}

Question 10 collects information about the learning styles preferred by students. According to the results in Table 4, students' most unfavorite learning style is "The teacher gives lectures to which I listen" (28.5\%). This result is in line with their responses to teachers' role in question 8 , that is, the class should not be totally dominated by teachers. Their most favored one is "The teacher gives lectures and also provides me with opportunities to practice" (73.8\%) which females $(80.4 \%)$ favor more than males $(60.3 \%)$ significantly, $\chi^{2}=2.70, d f=1, p=.001$. This result shows that except for teachers' explanations of the knowledge, students also need the chance to practice so that they can consolidate what have learned in the English course. It can be inferred that students need a classroom where they can benefit from both the teacher's guidance and the student's autonomy, rather than an excessively teacher-centered or student-centered classroom that offers either total authority or complete freedom.

\section{Affective Perspective}

Question 11 is concerned with the students' English learning motivations (Appendix D). The usefulness of English is the primary motivation chosen by the most students $(68.8 \%)$, which demonstrates students' strong instrumental motivation (Gao, et al., 2003). In contrast, only 7.2\% of students choose "Because my parents want me to learn English" and $21.7 \%$ of students select "Because the school requires me to study English", which demonstrates that most students' disfavors of the pressure from schools and parents. As for significant gender differences, more females (34.2\%) are motivated by schools' requirements of learning English than males $(15.5 \%), \chi^{2}=10.06, d f=1, p=.002$; more females $(35.8 \%)$ are stimulated by their expectations of getting decent academic performances than males $(15.1 \%), \chi^{2}=$ $10.22, d f=1, p=.001$. On the other hand, more males $(54.8 \%)$ view "Because I want to understand English book" as their motivation than females $(35.6 \%), \chi^{2}=8.19, d f=1, p=.004$.

TABLE V.

STUDENTS' ATTITUDE AND CONFIDENCE WHEN LEARNING ENGLISH

\begin{tabular}{llllllllll}
\hline Q12 & Gender & Never & Sometimes Often & Mean & SD & df & t & Sig. (2-tailed) \\
\hline & Male & $8.2 \%$ & $60.3 \%$ & $31.5 \%$ & 2.23 & 0.59 & & & \\
& Female & $16.2 \%$ & $60.8 \%$ & $23.0 \%$ & 2.07 & 0.62 & 219 & 1.89 & .061 \\
& Total & $13.6 \%$ & $60.6 \%$ & $25.8 \%$ & 2.12 & 0.62 & & & \\
\hline Q13 & Gender & No & Sometimes & Yes & Mean & SD & df & t & Sig. (2-tailed) \\
\hline & Male & $16.4 \%$ & $52.1 \%$ & $31.5 \%$ & 2.15 & 0.68 & & & \\
& Female & $20.3 \%$ & $63.5 \%$ & $16.2 \%$ & 1.96 & 0.60 & 129.40 & 2.04 & .044 \\
& Total & $19.0 \%$ & $59.7 \%$ & $21.3 \%$ & 2.02 & 0.64 & & & \\
\hline
\end{tabular}

Students' attitude and confidence when learning English are explored by question 12 and question 13 respectively. According to the results in Table 5, only $13.6 \%$ of students never regard studying English as enjoyable while only $19 \%$ 
of students record having no confidence in making progress in English (Table 5). This shows students' overall positive attitude and strong confidence in learning English. One significant gender difference is that males $(M=2.15, S D=0.68)$ are more confident than females $(M=1.96, S D=0.60)$ in learning English, $t(129.40)=2.09, p=.044$.

\section{CONCLUSION}

\section{A. Discussions and Implications for EGP Courses Development and Teaching}

To start with, there should be an attempt to satisfy the needs of students revealed in this study. More pronunciation exercises and speaking activities could be adopted to meet students' desires of practicing pronunciation and speaking in the class. More communicative tasks could also be included in the EGP courses in view of students' preference for communicative learning activities, such as information gaps, role-plays, and simulations, thereby providing students with more opportunity to use English to communicate in diverse situations (Nunan, 2015). Further to this, to align with the needs of students, teachers should attempt to create a harmonious learning environment and offer positive feedback to students during the teaching process. The results further highlight the importance placed by students on both the leading role of teachers and the central position of students in the classroom. Therefore, teachers could adopt the blended "teacher-led and student-centered" teaching model, with an equal emphasis placed on both learning and teaching (He, p. 3, 2004).

In addition, the conflict in students' opinions of vocabulary should be noted. The results show that students' perceptions of vocabulary as the most indispensable English component contradict their choices of vocabulary as the component they are least eager to practice in class. There are two possible reasons for this. Firstly, the relatively short period of systematic English learning may result in low-grade students failing to comprehend the future direction of learning, leading to their decreased ability in making beneficial decisions regarding language development and progress. Teachers could resolve this issue by providing each student with an individual and appropriate learning plan according to their specific learning habits or characteristics, which would enable students to arrange their English vocabulary learning more successfully. Following the learning plan and the teacher's instruction may help students to clarify appropriate ways of scheduling English vocabulary learning and improve their ability to adjust the current learning plan or create a new one in recognition of their own decisions and needs. Secondly, students may deem it unnecessary to contribute extra time to learning vocabulary in a traditional classroom. The continuous development of mobile learning theory and cellphone application technology has led to many English vocabulary learning apps appearing. In comparison to traditional vocabulary books, these apps offer many new and irreplaceable advantages. For example, the "Scallops English", a popular English vocabulary app in China, is beneficial for students in many ways: 1) learners can find the words they need easily while the relevant example sentences illustrate the usage and collocation of the word comprehensively; 2) convenience is offered through its instant automatic pronunciation function which enables learners to imitate, read and repeat words at any time; 3) the automatic review function provides students with review plans based on Ebbinghaus Forgetting Curves ${ }^{1}$ to help them form long-term memory of words (Li \& Wang, 2012). The advantages of learning apps may incite students to learn English through technology rather than through traditional classroom. However, technology and classroom learning do not need to be mutually exclusive. Teachers could cater to the preference of students by using apps to set up online vocabulary learning tasks and assign homework, which may lead to a better teaching result.

Finally, separate teaching strategies for males and females could be adopted based on several essential gender differences found in this study. Males reported higher recognition of the authoritative role of teachers in the classroom, alongside higher preference for practicing drills on grammar patterns and undertaking English-Chinese exercises. This suggests that when teaching male teachers could adopt a traditional teacher-centered classroom in which grammartranslation teaching methods could be used more frequently. General belief stipulates that the teacher-centered classroom is not conducive for improving the positivity of students, while the grammar-translation teaching method is further criticized for being monotonous with excessive emphasis placed on the prescriptive rules of language (Luo \& Shi, 2004). However, teachers need not be bound by these ideas and should instead seek to adopt the teaching strategies preferred by students. Because teaching attuned to the needs of students may, in turn, stimulate their interests in learning English and immerse them more deeply in the class (Nunan, 1988). In contrast, females reported a higher desire for a stress-free learning environment, positive feedback from teachers, and the opportunity to practice. This requires teachers to develop a student-centered English classroom when teaching females, in which harmonious relationships with students are prioritized and formed, with more time set aside for students to practice the English knowledge learned in class. During this practice, teachers may frequently encourage students and offer positive comments to build their confidence.

As one of the few needs analysis studies concerning the needs of Chinese English majors in EGP courses, it is expected that this study can stimulate the interest of other researchers regarding the critical issue of considering the importance of students' needs to develop EGP courses for Chinese English majors.

\section{B. Limitations and Suggestions}

\footnotetext{
1 Ebbinghaus Forgetting Curves refer to the law of peoples' loss of learned information.
} 
First, the sample size of this study is relatively small, with only 221 English majors selected, all of whom study at Tianjin Foreign Studies University. The subject of this study, therefore, is not wholly representative of Chinese English majors enrolled in EGP courses. Any future study may enlarge the sample source to generalize the result, selecting English majors from a range of universities to establish a more comprehensive identification of their needs.

Second, this study is not continuous. However, the on-going needs analysis is deemed crucial because course development is a dynamic process, meaning the intermittent variances of course requirements must be acknowledged and considered (Chen \& Wang, 2009). Needs analysis should navigate each stage of the entire process, including course setting, implementation, adjustment, and evaluation. By doing this, educators will be able to identify new needs and evaluate the course while ensuring that the developed course does not deviate from the original teaching goals established.

Third, this study fails to analyze the needs of students from a triangulated perspective. According to the Needs Analysis Triangle (West, 1994), the ideal data source for needs analysis contains three principal parties: teacherperceived needs, student-perceived needs, and company-perceived needs. By regarding only one data source, research results become relatively tendentious (Long, 2005), while cooperative interaction of these three parties would provide a more comprehensive and reliable identification of needs (West, 1994). Therefore, future researchers may carry out triangular mutual certification by collecting and comparing data from different sources, which may produce a more inclusive and dependable result.

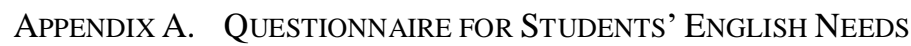

The purpose of the questionnaire is to see what your language needs are, and whether your needs are being met and, if not, what can be done better. Please let your true feelings and opinions be known when filling out this questionnaire. It would be appreciated if you complete this questionnaire, which would take approximately 15 minutes.

\section{Part A}

Please fill in the blanks with your personal information.

1. Age:

2. Gender:

3. Grade:

\section{Part B}

Please circle the corresponding number according to your actual situation. Only one number can be selected for each question. The larger the number you choose, the more in line with your actual ideas.

1=Low

2=Relatively Low

3=Moderate

4=Relatively High

5=High

1. In your study of English, how important is grammar, vocabulary, and pronunciation to you?

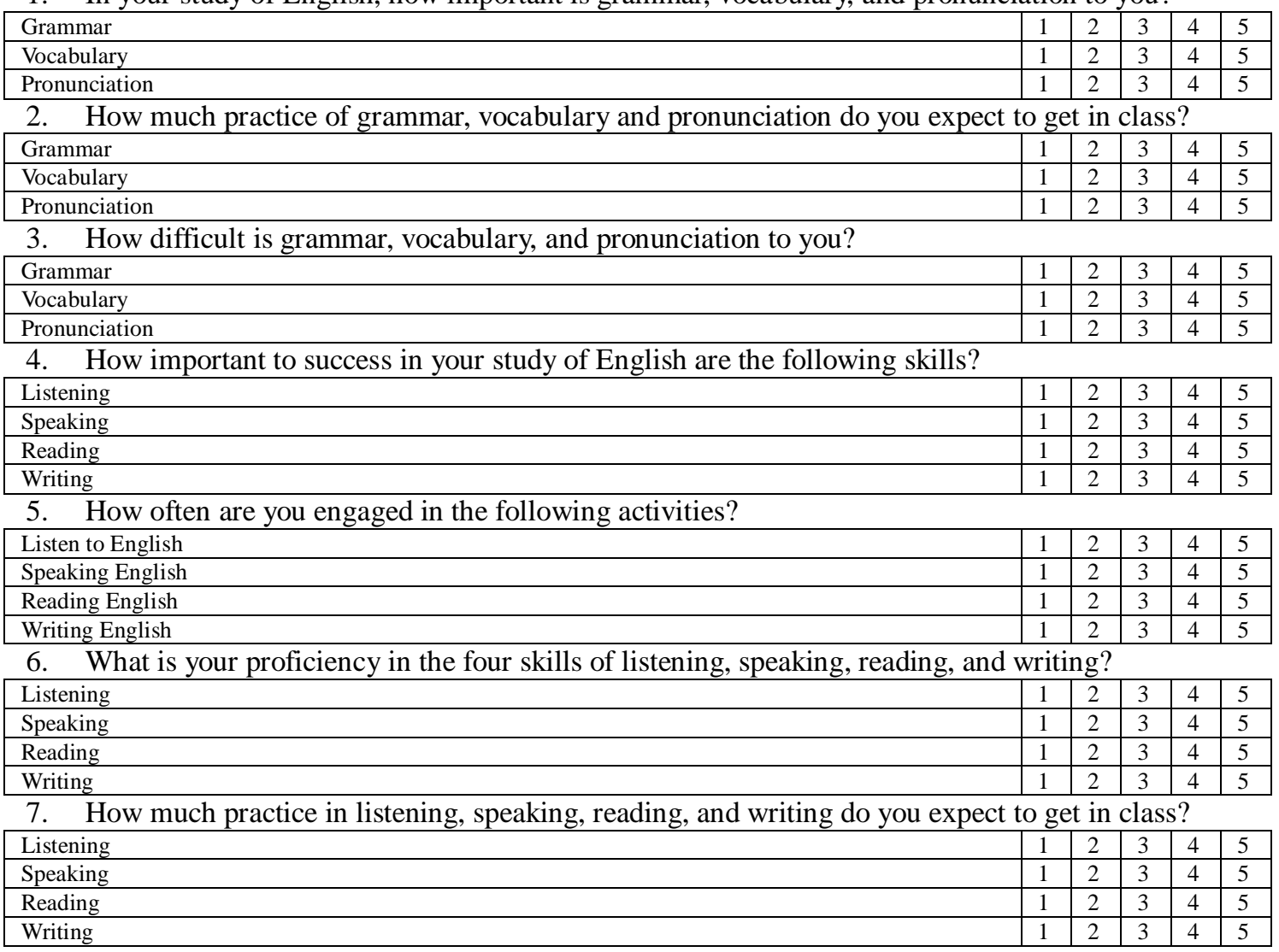




\section{Part C}

8. Choose the statements that best describe your opinions on what the English teacher should do. (You can choose more than one answer)

1) The teacher gives lectures and delivers knowledge.

2) The teacher is the "authority" in the classroom.

3 ) The teacher talks for most of the class time.

4) The teacher gives time for students to talk.

5) The teacher corrects every mistake that students make.

6) The teacher responds to students positively.

7) The teacher tries different activities in class.

8) The teacher encourages the students to ask questions.

9) The teacher should create a harmonious and pleasant learning environment.

10) The teacher should pay attention to students' needs.

11) The teacher uses the textbooks only.

12) The teacher teaches the students some learning strategies.

9. How useful are the following activities in studying English from your perspective?

\begin{tabular}{|c|c|c|c|}
\hline $1=$ Not useful & 3= Useful & & \\
\hline (1) Memorizing bilingual words list. & 1 & 2 & \\
\hline (2) Studying the grammar rules of English. & 1 & 2 & \\
\hline (3) Practicing drills on sounds, stress, and intonation of English. & 1 & 2 & \\
\hline (4) Practicing drills on grammar patterns. & 1 & 2 & \\
\hline (5) Reciting dialogues from a textbook. & 1 & 2 & \\
\hline (6) Doing English-Chinese exercises. & 1 & 2 & \\
\hline (7) Doing role play activities. & 1 & 2 & \\
\hline (8) Watching English movies. & 1 & 2 & \\
\hline (9) Listening to English music. & 1 & 2 & \\
\hline (10) Reading English novels and magazines. & 1 & 2 & \\
\hline (11) Writing English diaries. & 1 & 2 & \\
\hline (12) Writing emails in English. & 1 & 2 & \\
\hline (13) Chatting through Internet in English. & 1 & 2 & \\
\hline (14) Talking to friends in English. & 1 & 2 & \\
\hline (15) Talking to English speakers whenever I have the opportunity. & 1 & 2 & \\
\hline (16) Searching for learning resources out of class. & 1 & 2 & \\
\hline (17) Participating in English camp. & 1 & 2 & \\
\hline
\end{tabular}

10. What kind(s) of learning style(s) do you like? (You can choose more than one answer)

1) The teacher gives lectures to which I listen.

2) The teacher gives lectures and also provides me with opportunities to practice.

3 ) I study individually.

4) I discuss with my desk-mates.

5) I discuss with my group members.

Part D

11. Why do you study English? (You can choose more than one answer)

1) Because I like English.

2) Because English is an useful language.

3 ) Because the school requires me to study English.

4) Because I want to get a good school grade.

5) Because I want to travel to other countries.

6) Because I want to speak to foreigners.

7) Because I want to understand English pop songs.

8) Because I want to understand English movies.

9) Because I want to understand English books.

10) Because my parents want me to learn English.

12. Do you think studying English is an enjoyable experience? Please circle the appropriate response. Never $\quad$ Sometimes $\quad$ Often

13. Do you feel confident about the progress of your English? Please circle the appropriate response.

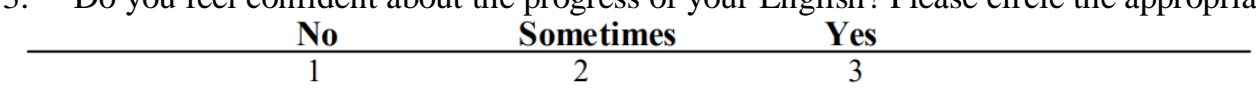


ApPendix B. Table Regarding Students' Opinions towards the Role OF EnGlish Teachers

\begin{tabular}{|c|c|c|c|c|c|}
\hline Q8 & Gender & Agree & df & $\chi^{2}$ & $\begin{array}{l}\text { Asymp.Sig. } \\
\text { (2-sided) }\end{array}$ \\
\hline \multirow{3}{*}{$\begin{array}{l}\text { The teacher gives lectures and delivers } \\
\text { knowledge. }\end{array}$} & Male & $43.8 \%$ & \multirow{3}{*}{1} & \multirow{3}{*}{22.91} & \multirow{3}{*}{.000} \\
\hline & Female & $76.4 \%$ & & & \\
\hline & Total & $65.6 \%$ & & & \\
\hline \multirow{4}{*}{$\begin{array}{l}\text { The teacher is the "authority" in the } \\
\text { classroom. }\end{array}$} & Male & $20.5 \%$ & \multirow{4}{*}{1} & \multirow{4}{*}{12.02} & \multirow{4}{*}{.001} \\
\hline & Female & $5.4 \%$ & & & \\
\hline & Total & $10.4 \%$ & & & \\
\hline & Male & $30.1 \%$ & & & \\
\hline \multirow[t]{3}{*}{ The teacher talks for most of the class time. } & Female & $20.9 \%$ & \multirow[t]{3}{*}{1} & \multirow[t]{3}{*}{2.27} & \multirow[t]{3}{*}{.132} \\
\hline & Total & $24.0 \%$ & & & \\
\hline & Male & $61.6 \%$ & & & \\
\hline \multirow[t]{2}{*}{ The teacher gives time for students to talk. } & Female & $67.5 \%$ & \multirow[t]{2}{*}{1} & \multirow[t]{2}{*}{.76} & \multirow[t]{2}{*}{.383} \\
\hline & Total & $65.6 \%$ & & & \\
\hline \multirow{4}{*}{$\begin{array}{l}\text { The teacher corrects every mistake that } \\
\text { students make. }\end{array}$} & Male & $37.0 \%$ & \multirow{4}{*}{1} & \multirow{4}{*}{.63} & \multirow{4}{*}{.427} \\
\hline & Female & $42.6 \%$ & & & \\
\hline & Total & $40.7 \%$ & & & \\
\hline & Male & $58.9 \%$ & & & \\
\hline \multirow[t]{3}{*}{ The teacher responds to students positively. } & Female & $77.7 \%$ & \multirow[t]{3}{*}{1} & \multirow[t]{3}{*}{8.48} & \multirow[t]{3}{*}{.004} \\
\hline & Total & $71.5 \%$ & & & \\
\hline & Male & $60.3 \%$ & & & \\
\hline \multirow[t]{2}{*}{ The teacher tries different activities in class. } & Female & $57.4 \%$ & \multirow[t]{3}{*}{1} & \multirow[t]{3}{*}{.16} & \multirow[t]{2}{*}{.687} \\
\hline & Total & $58.4 \%$ & & & \\
\hline & Male & $60.3 \%$ & & & \\
\hline guestions. & Female & $68.2 \%$ & 1 & 1.38 & .241 \\
\hline & Total & $65.6 \%$ & & & \\
\hline & Male & $54.8 \%$ & & & \\
\hline plesent learning environment & Female & $74.3 \%$ & 1 & 8.55 & .003 \\
\hline & Total & $67.9 \%$ & & & \\
\hline & Male & $56.2 \%$ & & & \\
\hline The teacher should pay attention to & Female & $60.8 \%$ & 1 & .44 & .508 \\
\hline & Total & $59.3 \%$ & & & \\
\hline & Male & $12.3 \%$ & & & \\
\hline The teacher uses the textbooks only. & Female & $14.2 \%$ & 1 & .14 & .704 \\
\hline & Total & $13.6 \%$ & & & \\
\hline The teacher teaches the students some & Male & $64.4 \%$ & & & \\
\hline learning strategies. & Female & $65.5 \%$ & 1 & .03 & .865 \\
\hline & Total & $65.2 \%$ & & & \\
\hline
\end{tabular}


ApPendix C. Table Regarding the Preferred Learning Activities of Students

\begin{tabular}{|c|c|c|c|c|c|c|}
\hline Q9 & Gender & Mean & SD & df & $\mathrm{t}$ & Sig.(2-tailed) \\
\hline \multirow{3}{*}{ Memorizing bilingual words list } & Male & 2.45 & 0.62 & \multirow{3}{*}{219} & \multirow{3}{*}{2.59} & \multirow{3}{*}{.010} \\
\hline & Female & 2.22 & 0.62 & & & \\
\hline & Total & 2.30 & 0.63 & & & \\
\hline \multirow{3}{*}{ Studying the grammar rules of English } & Male & 2.51 & 0.58 & \multirow{3}{*}{219} & \multirow{3}{*}{1.43} & \multirow{3}{*}{.153} \\
\hline & Female & 2.39 & 0.60 & & & \\
\hline & Total & 2.43 & 0.60 & & & \\
\hline \multirow{3}{*}{$\begin{array}{l}\text { Practicing drills on sounds, stress, and } \\
\text { intonation of English }\end{array}$} & Male & 2.53 & 0.63 & \multirow{3}{*}{219} & \multirow{3}{*}{2.34} & \multirow{3}{*}{.020} \\
\hline & Female & 2.33 & 0.60 & & & \\
\hline & Total & 2.40 & 0.61 & & & \\
\hline \multirow{3}{*}{ Practicing drills on grammar patterns } & Male & 2.42 & 0.60 & \multirow{3}{*}{219} & \multirow{4}{*}{2.57} & \multirow{3}{*}{.011} \\
\hline & Female & 2.20 & 0.61 & & & \\
\hline & Total & 2.28 & 0.61 & & & \\
\hline \multirow{3}{*}{ Reciting dialogues from a textbook } & Male & 2.16 & 0.75 & \multirow{4}{*}{128.04} & & \multirow{3}{*}{.074} \\
\hline & Female & 1.98 & 0.65 & & \multirow[t]{3}{*}{1.80} & \\
\hline & Total & 2.04 & 0.69 & & & \\
\hline & Male & 2.38 & 0.70 & & & \\
\hline Doing English-Chinese exercises & Female & 2.19 & 0.54 & 115.45 & 2.09 & .039 \\
\hline & Total & 2.25 & 0.60 & & & \\
\hline & Male & 2.21 & 0.73 & & & \\
\hline Doing role play activities & Female & 2.06 & 0.63 & 126.99 & 1.45 & .148 \\
\hline & Total & 2.11 & 0.67 & & & \\
\hline & Male & 2.40 & 0.70 & & & \\
\hline Watching English movies & Female & 2.26 & 0.58 & 122.66 & 1.48 & .142 \\
\hline & Total & 2.30 & 0.63 & & & \\
\hline & Male & 2.40 & 0.62 & & & \\
\hline Listening to English music & Female & 2.24 & 0.62 & 219 & 1.81 & .071 \\
\hline & Total & 2.29 & 0.62 & & & \\
\hline & Male & 2.51 & 0.60 & & & \\
\hline Reading English novels and & Female & 2.28 & 0.56 & 219 & 2.81 & .005 \\
\hline & Total & 2.35 & 0.58 & & & \\
\hline & Male & 2.27 & 0.67 & & & \\
\hline Writing English diaries & Female & 2.21 & 0.67 & 219 & 67 & .503 \\
\hline & Total & 2.23 & 0.67 & & & \\
\hline & Male & 2.33 & 0.67 & & & \\
\hline Writing emails in English & Female & 2.16 & 0.73 & 219 & 1.64 & .093 \\
\hline & Total & 2.22 & 0.71 & & & \\
\hline & Male & 2.47 & 0.60 & & & \\
\hline Chatting through Internet in English & Female & 2.27 & 0.70 & 219 & 2.05 & .042 \\
\hline & Total & 2.33 & 0.67 & & & \\
\hline & Male & 2.52 & 0.67 & & & \\
\hline Talking to friends in English & Female & 2.35 & 0.73 & 219 & 1.67 & .096 \\
\hline & Total & 2.41 & 0.71 & & & \\
\hline & Male & 2.58 & 0.60 & & & \\
\hline Talking to English speakers whenever & Female & 2.50 & 0.62 & 219 & .86 & .393 \\
\hline 1 have the opportunity & Total & 2.52 & 0.61 & & & \\
\hline & Male & 2.55 & 0.58 & & & \\
\hline Searching for learnıng resources out & Female & 2.39 & 0.62 & 219 & 1.87 & .063 \\
\hline & Total & 2.44 & 0.61 & & & \\
\hline & Male & 2.42 & 0.66 & & & \\
\hline Participating in English camp & Female & 2.20 & 0.74 & 219 & 2.23 & .027 \\
\hline & Total & 2.27 & 0.73 & & & \\
\hline
\end{tabular}


ApPendix D. TABle Regarding Motivations of Students FOR LEARning English

\begin{tabular}{|c|c|c|c|c|c|}
\hline Q11 & Gender & Agree & df & $\chi^{2}$ & $\begin{array}{l}\text { Asymp.Sig. } \\
\text { (2-sided) }\end{array}$ \\
\hline \multirow{3}{*}{ Because I like English. } & Male & $52.8 \%$ & \multirow{3}{*}{1} & \multirow{3}{*}{3.36} & \multirow{3}{*}{.067} \\
\hline & Female & $64.9 \%$ & & & \\
\hline & Total & $60.6 \%$ & & & \\
\hline \multirow{3}{*}{ Because English is an useful language. } & Male & $65.8 \%$ & \multirow{3}{*}{2} & \multirow{3}{*}{2.33} & \multirow{3}{*}{.312} \\
\hline & Female & $70.3 \%$ & & & \\
\hline & Total & $68.8 \%$ & & & \\
\hline \multirow{3}{*}{$\begin{array}{l}\text { Because the school requires me to study } \\
\text { English. }\end{array}$} & Male & $15.5 \%$ & \multirow{4}{*}{1} & \multirow{4}{*}{10.06} & \multirow{4}{*}{.002} \\
\hline & Female & $34.2 \%$ & & & \\
\hline & Total & $21.7 \%$ & & & \\
\hline \multirow{3}{*}{ Because I want to get a good school grade. } & Male & $15.1 \%$ & & & \\
\hline & Female & $35.8 \%$ & \multirow[t]{2}{*}{1} & \multirow[t]{2}{*}{10.22} & \multirow[t]{2}{*}{.001} \\
\hline & Total & $29.0 \%$ & & & \\
\hline \multirow{3}{*}{$\begin{array}{l}\text { Because I want to travel to other } \\
\text { countries. }\end{array}$} & Male & $54.8 \%$ & \multirow{4}{*}{1} & \multirow{4}{*}{.15} & \multirow{3}{*}{.698} \\
\hline & Female & $52.0 \%$ & & & \\
\hline & Total & $52.9 \%$ & & & \\
\hline \multirow{3}{*}{ Because I want to speak to foreigners. } & Male & $52.1 \%$ & & & \multirow{3}{*}{.779} \\
\hline & Female & $54.1 \%$ & \multirow[t]{2}{*}{1} & \multirow[t]{2}{*}{.080} & \\
\hline & Total & $53.4 \%$ & & & \\
\hline \multirow{3}{*}{$\begin{array}{l}\text { Because I want to understand English pop } \\
\text { songs. }\end{array}$} & Male & $35.6 \%$ & \multirow{3}{*}{1} & \multirow{3}{*}{.07} & \multirow{3}{*}{.787} \\
\hline & Female & $33.8 \%$ & & & \\
\hline & Total & $34.4 \%$ & & & \\
\hline \multirow{3}{*}{$\begin{array}{l}\text { Because I want to understand English } \\
\text { movies. }\end{array}$} & Male & $53.4 \%$ & \multirow{3}{*}{1} & \multirow{3}{*}{.01} & \\
\hline & Female & $54.1 \%$ & & & .930 \\
\hline & Total & $53.8 \%$ & & & \\
\hline & Male & $54.8 \%$ & & & \\
\hline Because I want to understand English & Female & $35.6 \%$ & 1 & 8.19 & .004 \\
\hline & Total & $56.1 \%$ & & & \\
\hline Because my parents want me to learn & Male & $6.8 \%$ & & & \\
\hline $\begin{array}{l}\text { Because my parents want me to learn } \\
\text { Enolish }\end{array}$ & Female & $7.4 \%$ & 1 & .03 & .875 \\
\hline & Total & $7.2 \%$ & & & \\
\hline
\end{tabular}

\section{REFERENCES}

[1] Ahour, T., \& Mohseni, F. (2015). Investigate EFL Learners' Perception of Needs: Necessities, Wants, and Lacks in Different Language Skills Taught in General English Courses. Modern Journal of Language Teaching Methods, 5(1), 236-241.

[2] Behzadi, A., \& Lashkarian, A. (2015). Iranian Undergraduate Students' Needs in English Courses for General and Specific Purposes. International Journal of English and Education, 4(3), 67-80.

[3] Belcher, D. D. (2006). English for Specific Purposes: Teaching to Perceived Needs and Imagined Futures in Worlds of Work, Study, and Everyday Life. TESOL Quarterly, 40(1), 133-156.

[4] Brown, J. D. (1995). The Elements of Language Curriculum: A Systematic Approach to Program Development. 20 Park Plaza, Boston: Heinle \& Heinle Publishers.

[5] Cai, J. (2019). Conflicts over Foreign Language Policies: Interdisciplinary English Talents or Pure English Talents. Journal of Northeast Normal University (Philosophy and Social Sciences)(04), 1-6.

[6] Cha, M. (2017). On the Humanistic Nature of the English Discipline and the Significance of the Humanities-Based Curriculum for English Majors Based on the National Guideline. Foreign Language and Culture, 1(1), 18-26.

[7] Chen, B., \& Wang, H. (2009). A Critical Review of Needs Analysis Studies in Foreign Language Teaching in China. Foreign Languages and Their Teaching (07), 18-21.

[8] Dudley-Evans, T., \& John, M. J. S. (1998). Developments in English for Specific Purposes: A Multi-Disciplinary Approach. Cambridge: Cambridge University Press.

[9] Far, M. M. (2008). On the Relationship between ESP \& EGP: A General Perspective. English for Specific Purposes World, $7(1), 1-11$.

[10] Gao, Y., Zhao, Y., Chen, Y., \& Zhou, Y. (2003). Motivation Types of Chinese College Undergraduates. Modern Foreign Languages, 26(1), 28-38.

[11] Guiyu, D., \& Yang, L. (2016). An Empirical Study on Business English Teaching and Development in China - A Needs Analysis Approach. Higher Education Studies, 6(2), 142-153.

[12] $\mathrm{Hu}, \mathrm{W}$. (2014). On the Training of English majors in China: Retrospect And Prospect. Foreign Language Teaching and Research (bimonthly), 46(01), 111-117.

[13] Hu, W., \& Sun, Y. (2006). On Strengthening Humanistic Education in the English Language Curriculum. Foreign Language Teaching and Research (05), 243-247.

[14] He, K. (2004). Viewing the New Development of Educational Technology Theory from Blending_Learning (a). E-education Research (03), 1-6.

[15] Hutchinson, T., \& Waters, A. (1987). English for Specific Purposes: A learner-centered approach. Cambridge: Cambridge University Press.

[16] Lan, R. (2009). On the Disciplinal Affiliation and Cultivating Aim of Foreign Language Discipline at Higher Education. Foreign Languages in China, 6(06), 4-8.

[17] Li, C., \& Wang, J. (2012). The Effect of Scallop English Apps on the Junior High School Students' Memory of English Word of and its Countermeasures. Journal of Teaching and Management (36), 135-136. 
[18] Li, J. (2014). Needs Analysis of Business English Undergraduates and the Implications to Business English Curriculum Design. Advances in Language and Literary Studies, 5(4), 33-37.

[19] Li, S. (2007). Situation analysis and needs analysis in Chinese EFL context: A case of a senior high school in south-west China. Celea Journal, 30(4), 17-28.

[20] Liu, J., Chang, Y., Yang, F., \& Sun, Y. (2011). Is what I need what I want? Reconceptualising college students' needs in English courses for general and specific/academic purposes. Journal of English for Academic Purposes, 10(4), 271-280.

[21] Long, M. (2005). Second Language Needs Analysis. Cambridge: Cambridge University Press.

[22] Luo, L., \& Shi, X. (2004). The historical review, current situation and prospect of grammar translation teaching method. Foreign Language Education (01), 84-86.

[23] Lü, X., Fu, J., \& Ruan, Y. (2014). A Probe into the Teaching Mode of Film and TV Courses for English Majors Based on Needs Analysis_-An Case Study of Communication University of China. Modern Communication, 36(09), 137-139.

[24] Mehrdad, A. G. (2012). A subjective needs assessment of EGP students. Procedia - Social and Behavioral Sciences, 31, 546554.

[25] Moiinvaziri, M. (2014). Students' Voice: A Needs Analysis of University General English Course in Iran. GEMA Online Journal of Language Studies, 14(01), 57-75.

[26] Munby, J. (1978). Communicative Syllabus Design. Cambridge: Cambridge University Press.

[27] Nouri, M., \& Mazdayasna, G. (2014). Tracking down the Academic Target Needs of Undergraduate Students of English Language and Literature in a Non-Native context. Journal of Foreign Language Teaching and Translation Studies, 3(1), 54-73.

[28] Nunan, D. (1988). The Learner-centered Curriculum. Cambridge: Cambridge University Press.

[29] Nunan, D. (2015). Teaching English to Speakers of Other Languages: An Introduction. New York: Routledge.

[30] Oanh, D. T. H. (2007). Meeting Students' Needs in Two EAP Programmes in Vietnam and New Zealand: A Comparative Study. RELC journal, 38(3), 324-349.

[31] Pourshahian, B., Gholami, R., Vaseghi, R., \& Kalajahi, S. A. R. (2012). Needs of an ESL Context: A Case Study of Iranian Graduate Students. World Applied Sciences Journal, 17(7), 870-873.

[32] Seedhouse, P. (1995). Needs analysis and the General English classroom. ELT Journal, 49(1), 59-65.

[33] Shu, D. (2004). Foreign Language Teaching Reform: Problems and Countermeasures. Shanghai: Shanghai Foreign Language Education Press.

[34] Su, W. (2011). An Investigation of the Needs of Interpretation Professional Courses from the Perspective of LearnersCase Study of Consecutive Interpretation Courses for Undergraduate Translation Majors in 4 Chinese Universities. Foreign Language World (05), 84-92.

[35] Wang, H. (2014). An Analysis of EFL Learners' Needs for Student-Centered Translation Course Design. Study in English Language Teaching, 2(1), 76-94.

[36] Wen, X., \& Wei, X. (2018). From Compound Talents to Holistic Education: Rethinking the Cultivation of Foreign Language Talents. Shandong Foreign Language Teaching (03), 50-60.

[37] West, R. (1994). Needs analysis in language teaching. Language Teaching, 27(1), 1-19.

[38] Xie, Q. (2016). Business Communication Needs of English Major Undergraduates and Curriculum Development in a Chinese University. The Asia-Pacific Education Researcher, 25(4), 667-676.

[39] Xie, Q. (2019). English Major Undergraduates' Needs and Perceptions of Business English Activities and Resources in a Chinese University. Journal of Language Teaching and Research, 10(4), 757-768.

[40] Ye, H., \& Wang, K. (2019). Needs Analysis and Curriculum Development for Legal English Majors Under the Guidance of 2018 National Standards. Foreign Language and Literature, 35(06), 1-10.

[41] Yu, Z. (2011). Research and Enlightenment of English for Specific Purpose Teaching Practice_— Taking "Electricity English" as an Example. Foreign Language World (05), 88-96.

[42] Zhang, J. (2018). The Construction of College English Curriculum Group. Heilongjiang Researches on Higher Education (2), $152-155$.

[43] Zhao, Q., Lei, L., \& Zhang, M. (2009). College English Teaching from the Perspective of Students' English Learning Needs. Foreign Language World (04), 14-22.

[44] Zhu, X. (2015). College English Curriculum Design Based on Learner Needs Analysis. Journal of Beijing Normal University (Social Sciences) (01), 97-103.

[45] Zhu, X, \& Ma, W. (2014). Analysis on the Needs of Learners in Curriculum Setting_ Based on the Research of College Public English Course. Foreign Language World (06), 48-56.

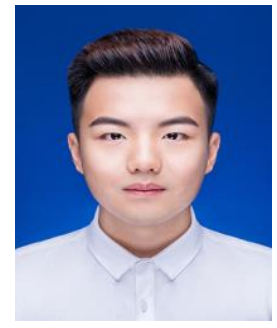

Kexin Xu is currently an undergraduate majoring in English translation at Tianjin Foreign Studies University. His research interests include applied linguistics, second language acquisition, and curriculum design. Email: xukexinlq@outlook.com 